\title{
Viewpoint
}

\section{Learning as cognition: a developmental process for organizational learning}

\author{
Rob E. Carpenter
}

Rob E. Carpenter is based at the Soules College of Business, University of Texas at Tyler, Tyler, Texas, USA.
C Rob E Carpenter.

Published by Emerald Publishing Limited. This article is published under the Creative Commons Attribution (CC BY 4.0) licence. Anyone may reproduce, distribute, translate and create derivative works of this article (for both commercial and non-commercial purposes), subject to full attribution to the original publication and authors. The full terms of this licence may be seen at http:// creativecommons.org/licences/ by/4.0/legalcode

\section{Introduction}

Today's organizational knowledge is vulnerable to obsolescence. To remain viable in a competitive environment requires individuals and organizations alike to constantly learn. Learning at the individual or group level is a substrate of human cognition. Human cognition can be described as the mental action or process of acquiring knowledge and understanding through thought. A mental action is the mindful representation (i.e. mental model) of possibilities. Intrinsic to any mental model is a perspective (Johnson-Laird, 2013). Perspective is the viewpoint from which learning as cognition ascribes.

A growing body of literature has placed learning as cognition as a leaver for developing organizational learning. Organizational learning literature is notable for two primary offerings on the entity seen as learning as cognition-learning as individual cognition and learning as group cognition. Learning as individual cognition is learning at the individual level of analysis and can be considered the individual agency of a member's capacity to learn and adapt their mental models at the level of the organizational system (Senge, 1990). Learning as group cognition incorporates the emergence of a collective agency - the groups belief about its perceived capacity to perform-as system level phenomenon (Grand et al., 2016). Each level of cognition has an associated perspectival state that may influence the development of organizational learning. The aim of this paper is to present a viewpoint of learning as individual and group cognition and ascribe perspective as important foci for organization learning.

\section{Learning as individual cognition}

Learning as individual cognition is the notion that humans acquire knowledge from a perspective of individual agency and denotes individual intentionality (Tomasello, 2018). Learning as individual cognition accounts for the employee's capacity for a new way of systems thinking. It implicitly informs the employee to adapt and become socialized. Adaptation infers the employee must perceive and negotiate environmental demands for a behavioral response. A behavioral response must be learned and cognized from an individual's perspective (Carcea and Froemke, 2019). In doing so, a behavioral response is oriented from the perspective of individual intentionality from the employee's subjective self.

Learning as individual cognition connotes an employees' mental model be developed from perspectival cues toward knowledge acquisition; then, knowledge carries the assimilated information forward to be systematically retrieved at a time of action. An employee's knowledge is a collection of isolated learning in some organized cognitive repository for a time when such knowledge extraction is needed. 
This notion is in line with Segne's (1990) systems thinking in organizational learning in that individuals learn systematically in an effort to develop perspective for how their organization works. The better understanding of an organizational system, the more apt employees are to introduce knowledge that prompts leverage for organizational results.

Learning as individual cognition can be considered a perspectival learning approach where each employee extracts a unique mental model based on their experience, knowledge, and skill. This perspective represents a particular underlying philosophyof-science logic consistent with theories of cognitive neuroscience by adopting the view that each brain constructs a behaviorally useful representation from, and of, the environment (Wong et al., 2019). However, this perspective is rooted in individual agency from a mode of individual acquisition. Operationally, this necessitates that employees be guided toward knowledge acquisition in terms of their own perspective and understanding of past knowledge and existing conceptualizations. An organization that creates a learning environment from only this perspective risks a point of departure from any joint or collective agency inherent to organizational learning.

\section{Learning as group cognition}

Whereas learning as individual cognition derives from a perspective of individual intentionality, learning as group cognition is the claim that a group can be the substrate of joint intentionality resulting in group cognition (Tomasello, 2018). Group cognition is the idea that groups can have emergent properties over and above the collection of the individual minds within the group.

Consider learning as group cognition as the recognition that groups are intentional subjects of learning and knowledge in their own right and are tethered to a particular cognitive perspective of joint intentionality. This inference is based upon causal and intentional relations within the group whereby group members begin to self-monitor their cognitive acts for group benefit. Thus, group learning and knowledge evolves from a perspective of participation, not acquisition. In cognitive acts of joint intentionality, group members formulate joint goals toward mutually beneficial joint intentions (Tomasello, 2016). A group's cognitive capacity can be argued to be the plural substrate of joint intentionality when group members pursue group goals structured by joint intention.

For example, the group cognition of a high performing workgroup is an extracted substrate insofar as the adaptive success of the group is dependent on group mental models that pluralistically exercise causal influence on joint intentionality. The group mental models are the perspectival cognitive representations that act to influences group performance (Tomasello, 2018). In this view, the perspective that what individual group members do (e.g. critical thinking, decision making) is not reflected as a manifestation of a singular mind but an outcome of group participation. This affords an interesting perspective that learning as group cognition is intersubjective, not merely subjective.

Operationally, this compels that learning as group cognition is guided by the perspective of joint intentionally and that its agency should be acquired through group participation. Organizations that create learning environments from this perspective recognize collaborative activity and joint focus engages an intersubjective agency of joint intention implicit to organizational learning.

\section{Cognition as a basis of organizational learning}

Cognition as a basis of organization learning comes into existent from a perspective of collective intentionally (Gibson and Earley, 2007). The idea that collectives are capable of 


\section{Keywords: Cognition, Group learning, Organizational learning, Collective cognition}

forming intentions is not new. Cognitive systems frequently cited as likely examples of collective intentionality would include the economic markets, a dance troupe, or the forging of ants.

Within the work organizational however, collective intentionality becomes a matter of determining how a cognitive system at higher level can incorporate lower level cognitive systems, and how collective systems can be emergent for synergist effects and organizational gain. That is, the development of organization learning subsumes the cognitive perspectives of individual, joint, and collective intentionality. As employees individually adapt to organizational systems they become group minded with intentions that are joint focused. Joint intentions evolve beyond a subjective ground to an intersubjective perspective. By extension, collective intentionality engages acts of thinking based upon an internalized "voice" of collective agency that constitutes acts of cognition based on objective representations (Tomasello, 2018). A shared vision is an example. Employee buy-in of a shared organizational vision can act as a lever for collective intentionality by highlighting salience and sharedness (Gibson and Earley, 2007). A shared vision is an important element for influencing organizational learning (Hoe, 2007).

\section{Conclusion}

What is distinctively relevant about this viewpoint of learning as cognition is that organizations that utilizes organizational learning as a management tool must orient learning around cognitive perspectives that are grounded in some level of intentionality. An organization that recognizes perspective as the agency of intentionality by which learning as cognition develops into organizational learning has a better opportunity to remain competitive.

\section{References}

Carcea, I. and Froemke, R.C. (2019), "Biological mechanisms for observational learning", Current Opinion in Neurobiology, Vol. 54, pp. 178-185.

Gibson, C.B. and Earley, P.C. (2007), "Collective cognition in action: accumulation, interaction, examination, and accommodation in the development and operation of group efficacy beliefs in the workplace", Academy of Management Review, Vol. 32 No. 2, pp. 438-458.

Grand, J.A., Braun, M.T., Kuljanin, G., Kozlowski, S.W. and Chao, G.T. (2016), "The dynamics of team cognition: a process-oriented theory of knowledge emergence in teams", Journal of Applied Psychology, Vol. 101 No. 10, pp. 1353-1385.

Hoe, S.L. (2007), "Shared vision: a development tool for organizational learning", development and learning in organizations", An International Journal, Vol. 21 No. 4, pp. 12-13.

Johnson-Laird, P.N. (2013), "The mental models perspective", in Reisberg, D. (Ed.), Oxford Library of Psychology. The Oxford Handbook of Cognitive Psychology, Oxford University Press, pp. 650-667.

Senge, P. (1990), "The fifth discipline: the art \& practice of the learning organization", Doubleday.

Tomasello, M. (2016), A Natural History of Human Morality, Harvard University Press.

Tomasello, M. (2018), A Natural History of Human Thinking, Harvard University Press.

Wong, N.H., Ban, H. and Chang, D.H. (2019), "Human depth sensitivity is affected by object plausibility", Journal of Cognitive Neuroscience, Vol. 32 No. 2, pp. 338-352. 


\section{About the author}

Rob E. Carpenter received his PhD in Human Resource Development (HRD) from the University of Texas at Tyler. He is currently the Chief Executive Officer of a healthcare investment firm and an adjunct faculty member at the University of Texas at Tyler Soules College of Business. Rob's research agenda is focused towards neuroscientific insights on sociality in the workplace environment. Rob E. Carpenter can be contacted at: rec@ rlventures.com

For instructions on how to order reprints of this article, please visit our website: www.emeraldgrouppublishing.com/licensing/reprints.htm

Or contact us for further details: permissions@emeraldinsight.com 